\title{
Muscle deoxyribonucleic acid (DNA) concentration response to sublethal effect of ethanol extract of Nicotiana tobacum on juvenile African catfish (Clarias gariepinus)
}

\author{
Nwakanma, H. O ${ }^{1 *}$., Okorafor-Nwosu, $\mathrm{A}^{1}$., Nwamba, H. O²., Ichu, B. C. ${ }^{1}$ \\ ${ }^{1} \mathrm{Xxxx}$ University, City, Country \\ 1Materials and Energy Technology Department, Projects Development Institute (PRODA), P.M.B. 01609, Enugu, Nigeria. \\ 2Applied Biology and Biotechnology Department, Enugu State University of Science and Technology (ESUT), P.M.B. \\ 01660, Enugu, Nigeria.
}

*Correspondence: brizeditor@gmail.com

\begin{abstract}
Advancement in human knowledge in the utilization of available natural resources to effect positive changes, though useful in achieving the desired purpose, but if not effectively regulated and monitored, may sometimes present undesired side challenges. The quest to achieve nutritional sufficiency to the ever increasing human population through fish production is not left out in this phenomenon. To this effect, this research is meant to understand the muscle deoxyribonucleic acid (DNA) concentration response to sublethal effect of ethanol extract of Nicotiana tobacum on juvenile African catfish (Clarias gariepinus). Experimental fish were acclimatized for 14 days before bioassay and ethanol extract of tobacco leaf (Nicotiana tobacum) was made. Central composite design (CCD) in response surface method was applied to make a design matrix consisting of five design points per parameter or study factor. The study factors include exposure time, extract (pollutant) concentration and fish quantity per aquaria. Maximal effect condition as well as significant interactions were obtained and presented in contour and three dimensional plots. Individual effect of process conditions were studied as well. From the central composite design (CCD), process condition that has the maximum effect on DNA concentration in the fish muscle is; exposure time at 120 hours, extract concentration at $0.25 \mathrm{mg} / \mathrm{l}$ and fish quantity at 6 . It was observed from the study on individual effects, that the process factors caused reduction in muscular DNA concentration of the African catfish (Clarias gariepinus).
\end{abstract}

Keywords: Clarias gariepinus, Deoxyribonucleic acid, Nicotiana tobacum.

\section{Introduction}

Natural plant materials have proven overtime to exhibit piscicidial and pesticidial effects. They are less expensive and more environmentally friendly when compered to commercial chemical based agro pesticides. Most farmers in commercial and subsistence practice have applied natural plant materials before stocking of their aquaria to kill pests which might be harmful to the fish. After application and clean up, trace concentration of these plant materials may still be present in sublethal concentration which may be harmful to the fish physiology. Following this effect we wish to study the muscle DNA concentration response to sublethal effect of ethanol extract of Nicotiana tobacum on juvenile African catfish (Clarias gariepinus). Ethanol have proven to be a better phytochemicals extraction solvent than water ${ }^{[1]}$.

\section{Literature Review}

Aquaculture in Nigeria is a growing industry, which is expected to continue due to the needs to meet up with a large difference (over a million tonnes) between fish production and consumption. The aquaculture industry in Nigeria is restricted to inland freshwater aquaculture, despite abundant marine water resources, and only a few species such as Clarias, tilapia and carps are being cultured. Nigeria imports about 0.72 million tonnes of frozen fish that was valued at over \$US 500 million annually, this ranked Nigeria as the highest importer of seafood in Africa ${ }^{[2]}$. The history of fish culture in Nigeria can be dated back to 1951 when the feasibility of farming common carp Cyprinus carpio and tilapia in Panyam, Jos and Onikan, Lagos, respectively, were tested simultaneously ${ }^{[3]}$.

In terms of animal protein, in Nigeria, more money is spent to buy sea foods which include fish compared to meats ${ }^{[4]}$. African catfish, Clarias gariepinus Burchell, 1822 is of great commercial importance both in fisheries and aquaculture. $C$. gariepinus is a native species of Africa and has drawn attention of aquaculturists because of its biological attributes that include faster growth rate, resistance to diseases and

[Received xx Xxx 2019; Accepted xx Xxx 2019; Published (online) 30 Sep 2020] Publisher's Note: RCLSS stays neutral regard to jurisdictional claims published maps (c) (1) 
possibility of high stocking density ${ }^{[5]}$. It has an almost Pan African distribution (absent from Maghreb, the upper and lower Guinea, the Cape province, probably Nogal province), and also naturally occurs Jordan, Israel, Lebanon, Syria and southern Turkey ${ }^{[6]}$.

Nicotiana tobacum popularly called tobacco is a native of tropical and subtropical America, which is now cultivated worldwide in commercial quantity ${ }^{[7]}$. Tobacco contains the following phytochemicals: Nicotine, Anabasine (an alkaloid similar to the nicotine but less active), Glucosides (tabacinine, tabacine), 2,3,6-Trimethyl-1,4-naphthoquinone, 2-Methylquinone, 2-Napthylamine, Propionic acid, Anatalline, Anthalin, Anethole, Acrolein, Anatabine, Cembrene, Choline, Nicotelline, Nicotianine and Pyrene and they are generally recognized as being narcotic. This property makes it useful as narcotics, mulluscicides, piscicides, an anesthetic and pesticide ${ }^{[8]}$.

Central composite design (CCD) is a statistical tool applied in making multilevel matrix design to determine optimal effect combination, analysis of variance (ANOVA) to observe significant variables, and interaction plots such as 3D plots and contour plots to observe combination effects.

\section{METHODOLOGY}

\section{Experimental Nicotiana tobaccum}

Fresh leaves of Nicotiana tobacum were collected from local traders in Enugu. The leaves were identified with the aid of Odugbemi ${ }^{[9]}$. The leaves were washed and sun dried at ambient temperature. The dried leaves were blended using a clean kitchen blender to powdery form. It was sieved using a 250 ųm net to get uniform fine particles. Ethanol extract was prepared from the sieved sample using a soxhlet apparatus. After extraction, the solution was dried (removal of ethanol) using a vacuum dryer. The ethanol extract of Nicotiana tobaccum was kept in sample bottle while in use.

\section{Experimental African catfish (Clarias gariepinus)}

Ninety juveniles of African catfish (Clarias gariepinus) with mean weight of $18.67 \pm 0.061 \mathrm{~g}$, were procured from a local fisheries and transported to the laboratory in aerated polythene bags. The Clarias gariepinus juveniles were acclimatized in calibrated $50 \mathrm{~L}$ plastic aquarium for a period of 14 days in filtered and deionized tap water. The juveniles were fed twice daily using coppen commercial supplementary feed ( $42 \%$ protein content). During the acclimation period, water was change daily to prevent accumulation of toxic waste which tends to make the water alkaline. Acclimation and bioassay were done at ambient conditions and aquaria covered with net to allow exchange of gas and prevent deposition of solids as well. Feeding of the juveniles was discontinued a day before the bioassay.

Fractional factorial design of experiment using response surface method (RSM) to determine DNA concentration on juvenile catfish exposed to ethanol extract of Nicotina tobaccum.

Design Expert software (version 11.0) was used in this study to design the experiment and to determine combination effects of process parameters. The experimental design employed in this work is a two-level, five factor fractional factorial design, which programme output is 20 experiments. The dependent variable (response) is the concentration of DNA while the independent variables are exposure time (hours), extract concentration (mg/l), quantity of fish. Five study points were used in order to predict a good estimation of errors and experiments were performed in a randomized order. The actual and coded levels of each factor are shown in Table 3.1. The coded values were designated by -2 (minimum), -1 (mid-minimum), 0 (centre), +1 (midmaximum) and +2 (maximum). The design that can fit this model should have at list three consistent levels per variable [10]. This is justified by the central composite design (CCD) which has five levels per variable. Total number of experiments was determined using the following relation:

$\mathrm{N}=2^{\mathrm{n}}+2 \mathrm{n}+\mathrm{n}_{\mathrm{o}} \ldots \ldots \ldots \ldots \ldots \ldots \ldots \ldots \ldots$ equ. (1)

Where $\mathrm{N}$ is the total number of experiments, $\mathrm{n}$ is the number of variables and $n_{o}$ is the number of center points. This design model using CCD is useful to establish a relationship between the independent variables ( $\mathrm{x}$ variables) and dependent variables (response variables or y variables), to determine, through hypothesis testing, significance of the factors whose levels are represented ${ }^{[10]}$, and to determine the set of interaction that most affected DNA concentration in the test muscle tissue. It is noteworthy to point out that the software uses the concept of the coded values for the investigation of the significant terms, thus studying the effect of the variables on the response using coefficience equation, normal plot of standardized effect, normal probability scatter plot, interaction plot and 3D plots.

$10 \mathrm{~g}$ of catfish muscle was cut into a ceramic crucible (mutter). It was mixed with $600 \mu 1$ of extraction buffer and properly macerated to form paste. The paste was transferred into a new vial and kept in a water bath at $37^{\circ} \mathrm{c}$ for 1 minute for complete hydrolysis of tissue and release of DNA. The vial was kept again in water bath at $55^{\circ} \mathrm{c}$ for another 1 hour. This is to destroy all non DNA components in the sample. The vial was centrifuged at 5,000 rpm for 10 minutes. $300 \mu 1$ of the supernatant was carefully transferred to another vial without disturbing the pellets. $200 \mu \mathrm{l}$ of the reagent; phenol: chloroform: isoamyl alcohol in the ratio, 20:24:1 were added to the vial containing the supernatant. The whole solution was mixed by inverting the vial approximately 5 times by hand. The vial was centrifuged at $12,000 \mathrm{rpm}$ for 10 minutes. Two distinct layers were observed, a bottom organic layer and a top algrease layer. The top layer was separated to fresh vial without disturbing the bottom layer. The fresh vial before addition of the supernatant contain a mixture of chloroform : 
isoamyl alcohol in the ratio 24:1. The pipette used is rinsed each time a new reagent was taken. The vial content was mixed by inverting. It was centrifuged at $1,000 \mathrm{rpm}$ for 10 minutes. was dissolved in $10 \%$ perchloric acid. This was done by introducing the extract into a glass test tube and addition of $10 \mathrm{ml}$ of $10 \%$ perchloric acid. The whole solution was heated to dissolve.

\begin{tabular}{|c|c|c|c|c|c|}
\hline \multicolumn{2}{|l|}{ Factor } & \multicolumn{2}{|l|}{ Units } & Low level & High level \\
\hline \multicolumn{2}{|c|}{ Exposure time (A) } & \multicolumn{2}{|l|}{ Hours } & $24(-2)$ & $120(+2)$ \\
\hline $\begin{array}{l}\text { Extract } \\
\text { (B) }\end{array}$ & concentration & \multicolumn{2}{|l|}{$\mathrm{Mg} / \mathrm{L}$} & $100(-2)$ & $500(+2)$ \\
\hline \multicolumn{4}{|c|}{ Fish quantity (C) } & $3(-2)$ & $15(+2)$ \\
\hline \multirow{3}{*}{ Run } & Factor 1 & Factor 2 & Factor 3 & $\begin{array}{l}\text { Actual } \\
\text { Response }\end{array}$ & $\begin{array}{l}\text { Predicted } \\
\text { Response }\end{array}$ \\
\hline & $\begin{array}{l}\text { A:Exposure } \\
\text { time }\end{array}$ & $\begin{array}{l}\text { B:Extract } \\
\text { conc. }\end{array}$ & $\begin{array}{l}\text { C:Fish } \\
\text { quantity }\end{array}$ & DNA conc. & DNA conc. \\
\hline & Hours & $\mathrm{mg} / \mathrm{l}$ & No. & microgram/ml & $\mathrm{microgram} / \mathrm{ml}$ \\
\hline 1 & 24 & 0.25 & 3 & 308.41 & 306.64 \\
\hline 2 & 24 & 1.25 & 15 & 302.77 & 302.54 \\
\hline 3 & 72 & 0.25 & 15 & 296.05 & 293.34 \\
\hline 4 & 24 & 0.75 & 9 & 313.28 & 313.79 \\
\hline 5 & 96 & 1.00 & 6 & 261.72 & 266.57 \\
\hline 6 & 24 & 0.75 & 9 & 313.28 & 313.79 \\
\hline 7 & 24 & 0.25 & 12 & 311.03 & 317.3 \\
\hline 8 & 120 & 1.00 & 15 & 279.66 & 280.12 \\
\hline 9 & 72 & 0.75 & 3 & 265.18 & 269.55 \\
\hline 10 & 120 & 1.00 & 15 & 279.66 & 280.12 \\
\hline 11 & 72 & 0.75 & 3 & 265.18 & 269.55 \\
\hline 12 & 72 & 1.25 & 9 & 270.05 & 272.26 \\
\hline 13 & 24 & 1.25 & 3 & 298.89 & 300.26 \\
\hline 14 & 120 & 1.25 & 3 & 254.73 & 249.24 \\
\hline 15 & 48 & 1.00 & 6 & 292.21 & 287.11 \\
\hline 16 & 120 & 0.25 & 6 & 287.65 & 287.85 \\
\hline 17 & 48 & 0.50 & 6 & 303.44 & 293.8 \\
\hline 18 & 120 & 0.25 & 6 & 287.65 & 287.86 \\
\hline 19 & 72 & 1.25 & 9 & 270.05 & 272.26 \\
\hline 20 & 48 & 1.00 & 12 & 295.28 & 294.25 \\
\hline
\end{tabular}

\section{Extraction and analysis of DNA from catfish muscle}

The content of the tube was separated to two layers. The supernatant is transferred to a new vial and $100 \mu \mathrm{l}$ of $3 \mathrm{~mol}$ sodium acetate added. $100 \mu \mathrm{l}$ of ice cold ethanol stored in an ice box was added. The solution was mixed by inverting the vial slowly. The tip (bottom) of the vial was taped. The DNA strands were visible when observed against light. The vial was centrifuged at $10,000 \mathrm{rpm}$ for 10 minutes. The supernatant was decanted to get the pellets. The pellets were washed in $70 \%$ alcohol using a pipette. It was further centrifuged at $10,000 \mathrm{rpm}$ for 10 minutes. The supernatant (ethanol) was removed using a pipette and the vial kept at room temperature for ethanol to evaporate. The vial was dried on a blotting paper to collect DNA extract. The DNA extract
Equal volume $(10 \mathrm{ml})$ of $4 \%$ diphenylamine in glacial acetic acid was added. $0.25 \mathrm{ml}$ of aqueous $1.6 \%$ acetaldehyde was added. The whole solution was mixed and incubated over night at $30^{\circ} \mathrm{c}$. The developed DNA solution was transferred to a cuvet and absorbance determined in a ultra violet spectrometer (uv spec.) at $260 \mathrm{~nm}$ and $320 \mathrm{~nm}$. 260nm is the wavelength where DNA absorbs light most strongly, while $320 \mathrm{~nm}$ is meant for turbidity adjustment.

DNA concentration $(\mu \mathrm{g} / \mathrm{ml})=\left(\mathrm{A}_{260}\right.$ reading $-\mathrm{A}_{320}$ reading $)$ $\times$ dilution factor $\times 50 \mu \mathrm{g} / \mathrm{ml})$

Hint; $A_{260}$ of $1=50 \mu \mathrm{g} / \mathrm{ml}$

\section{Results And Discussion}


Essential reason for determination for DNA concentration in muscle of juvenile Clarias gariepinus, is to assess the effect of varied concentration of Nicotiana tobacum as time varies, knowing that DNA is a useful genetic marker. Nucleic acid is a primary determinant for capability for synthesis of protein.

\section{Matrix design and analysis of DNA concentration}

Table 2: laboratory actual and predicted (software generated) response for matrix design of ethanol extract of Nicotiana tobaccum effect on DNA concentration in the muscle tissue of juvenile Clarias gariepinus.

Matrix design model with study range as shown in table 1 was used to determine the combined conditions that had empirical relationship between DNA concentration and three independent variables in coded values was obtained using the statistical package Design-Expert 11.0 trial version to determine interactions among the factors as they affect DNA concentration is given by the equation below.

A quadratic regression equation that fitted the data is:

$\mathrm{Y}=283.756-15.6022 \mathrm{~A}-9.5562 \mathrm{~B}+7.43949 \mathrm{C}-$

$5.16799 \mathrm{AB}+4.71226 \mathrm{AC}-1.13047 \mathrm{BC}+14.8246 \mathrm{~A}^{2}-$ $1.64652 B^{2}-6.62059 C^{2}$

.equ. 2

Where $\mathrm{Y}$ is the response of the variables (DNA concentration) and A-C are the coded values of the

\begin{tabular}{|c|c|c|c|c|c|c|}
\hline Source & $\begin{array}{l}\text { Sum of } \\
\text { Square } \\
\text { S }\end{array}$ & df & $\begin{array}{l}\text { Mean } \\
\text { Square }\end{array}$ & $\begin{array}{l}\text { F- } \\
\text { value }\end{array}$ & p-value & Comment \\
\hline Model & 6255.21 & 9 & 695.02 & $\begin{array}{l}1048 . \\
14\end{array}$ & $\begin{array}{l}< \\
0.0001\end{array}$ & significant \\
\hline $\begin{array}{l}\text { A- } \\
\text { Exposur } \\
\text { e time }\end{array}$ & 2727.68 & 1 & $\begin{array}{l}2727.6 \\
8\end{array}$ & $\begin{array}{l}4113 . \\
54\end{array}$ & $\begin{array}{l}< \\
0.0001\end{array}$ & \\
\hline $\begin{array}{l}\text { B- } \\
\text { Extract } \\
\text { conc. }\end{array}$ & 947.06 & 1 & 947.06 & $\begin{array}{l}1428 . \\
24\end{array}$ & $\begin{array}{l}< \\
0.0001\end{array}$ & \\
\hline $\begin{array}{l}\text { C-Fish } \\
\text { quantity }\end{array}$ & 542.02 & 1 & 542.02 & $\begin{array}{l}817.4 \\
1\end{array}$ & $\begin{array}{l}< \\
0.0001\end{array}$ & \\
\hline $\mathrm{AB}$ & 183.15 & 1 & 183.15 & $\begin{array}{l}276.2 \\
0\end{array}$ & $\begin{array}{l}< \\
0.0001\end{array}$ & \\
\hline $\mathrm{AC}$ & 125.64 & 1 & 125.64 & $\begin{array}{l}189.4 \\
8\end{array}$ & $\begin{array}{l}< \\
0.0001\end{array}$ & \\
\hline $\mathrm{BC}$ & 6.80 & 1 & 6.80 & 10.26 & 0.0094 & \\
\hline $\mathrm{A}^{2}$ & 757.75 & 1 & 757.75 & $\begin{array}{l}1142 . \\
73\end{array}$ & $\begin{array}{l}< \\
0.0001\end{array}$ & \\
\hline $\mathrm{B}^{2}$ & 8.40 & 1 & 8.40 & 12.66 & 0.0052 & \\
\hline $\mathrm{C}^{2}$ & 134.71 & 1 & 134.71 & $\begin{array}{l}203.1 \\
5\end{array}$ & $\begin{array}{l}< \\
0.0001\end{array}$ & \\
\hline Residua & 6.63 & 10 & 0.6631 & & & \\
\hline $\begin{array}{l}\text { Lack of } \\
\text { Fit }\end{array}$ & 6.63 & 5 & 1.33 & $\begin{array}{l}1.326 \\
E+05\end{array}$ & $\begin{array}{l}< \\
0.0001\end{array}$ & significant \\
\hline $\begin{array}{l}\text { Pure } \\
\text { Error }\end{array}$ & 0.0000 & 5 & $\begin{array}{l}1.000 \mathrm{E} \\
-05\end{array}$ & & & \\
\hline $\begin{array}{l}\text { Cor } \\
\text { Total }\end{array}$ & 6261.84 & 19 & & & & \\
\hline
\end{tabular}

greatest effect on DNA concentration in juvenile African catfish. The design elements consist of independent and dependent variables. Independent variables are coded in the form; A-exposure time, B-extract concentration and C-fish quantity. Dependent variable is the response which is DNA concentration. The dependent variable (DNA concentration) depends on the interaction among independent variables. The independent variables. The above equation represents the quantitative effect of the factors (A, B and C) upon the response (Y). Equation 2 suggests that the independent variables had linear and quadratic interactions. Coefficients with one factor represent the single effect of that particular factor while the coefficients with more than one factor represent the interaction between those factors. Positive sign 
in front of the terms indicates synergistic effect while negative sign indicates antagonistic effect of the subsequent factors.
DNA concentration as it has the highest F-test value (4113.54) for single effect while the least was fish quantity (C) which has lowest F-test values of (817.41).

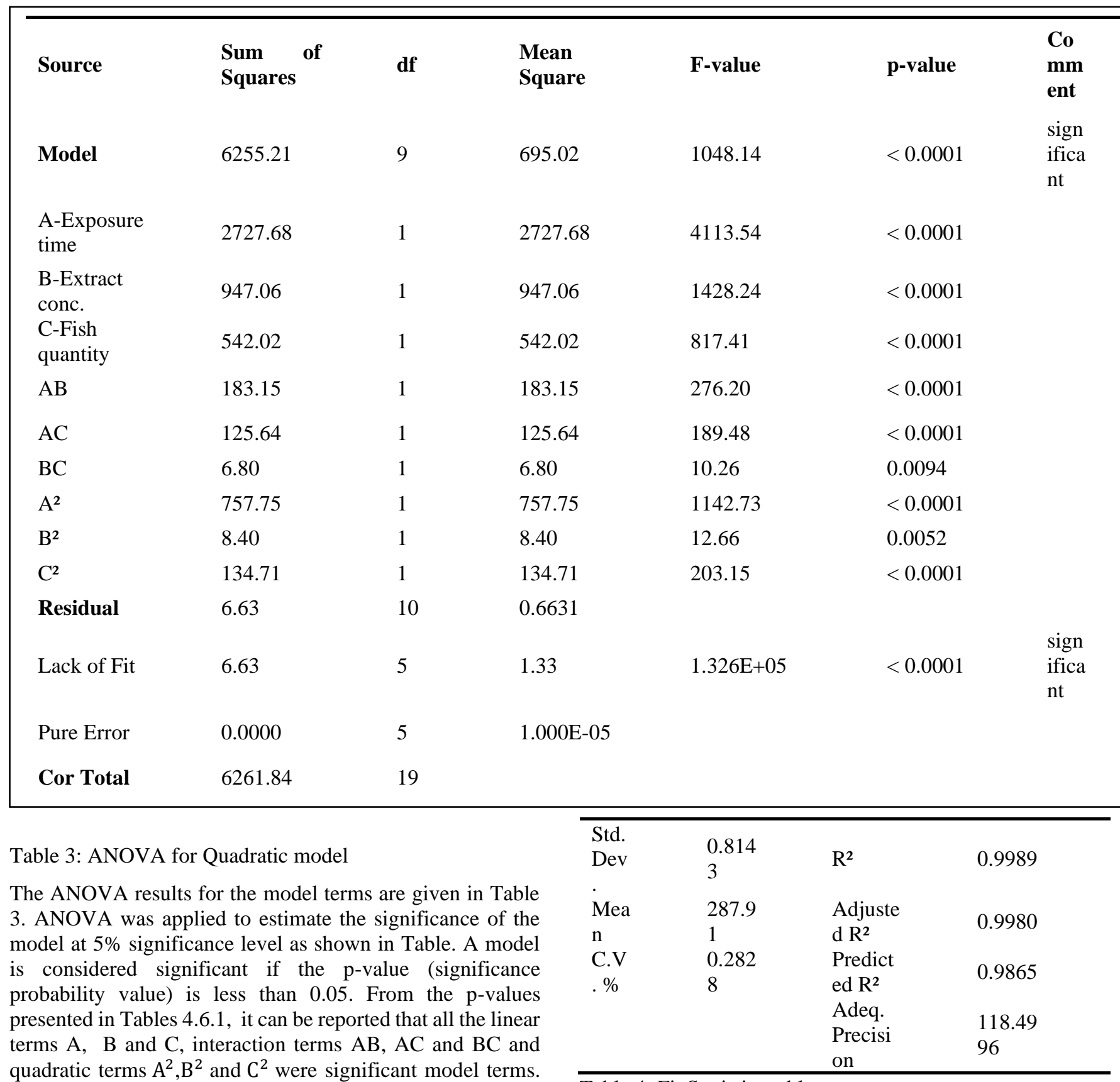

Based on this, it is evident that their were no insignificant variable in the relationship. If present it (they) would have been removed, the model adjusted to obtained a relationship which is a function of the more significant variables.

From Table 3, it was clearly shown that among the three variables studied, Exposure time (A) has the largest effect on
Table 4: Fit Statistics table

The adequacy of the above proposed model was tested using the Design Expert sequential model sum of squares and the model test statistics. From the statistical analysis, the regression coefficient $\left(\mathrm{R}^{2}=0.9989\right)$, the Predicted $\mathrm{R}^{2}$ of 0.9865 is in reasonable agreement with the Adjusted $R^{2}$ of 
0.9980 ; i.e. the difference is less than 0.2. The test result is shown in Table 4 (fit statistics). The coded equation is useful for identifying the relative impact of the factors by comparing the factor coefficients.
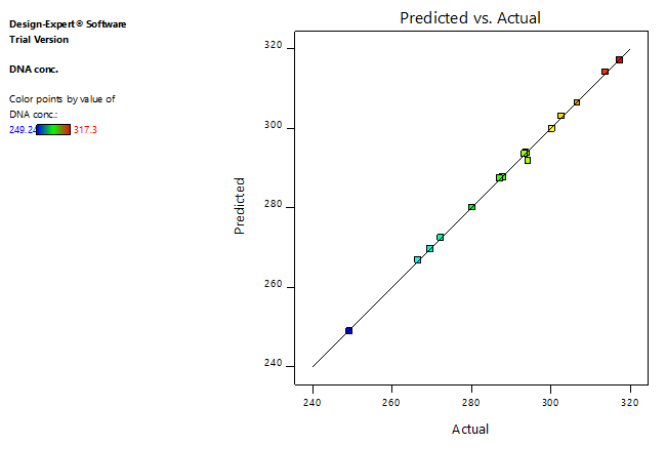

Fig. 1: Predicted vs actual plot

The correlation between the experimental and predicted DNA concentration from the actual and predicted values is shown in the plot, figure 1 above. Data points on the plot were linearly distributed, indicating a good relationship between the experimental and predicted values of the response. It also suggests that the quadratic model was proper and adequate in predicting the response variables for the experimental data.

\section{Three dimensional and contour surface plots for DNA} concentration

Dual interaction effect of process conditions on DNA concentration in African catfish muscle affect by ethanol extract of Nicotina tobaccum were captured in contour and three dimensional surface plots.

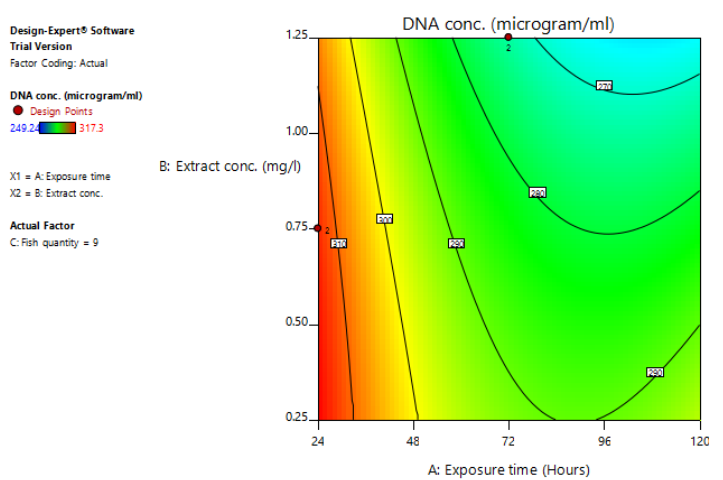

Fig. 2: Contour plot for interaction effect between exposure time and extract concentration

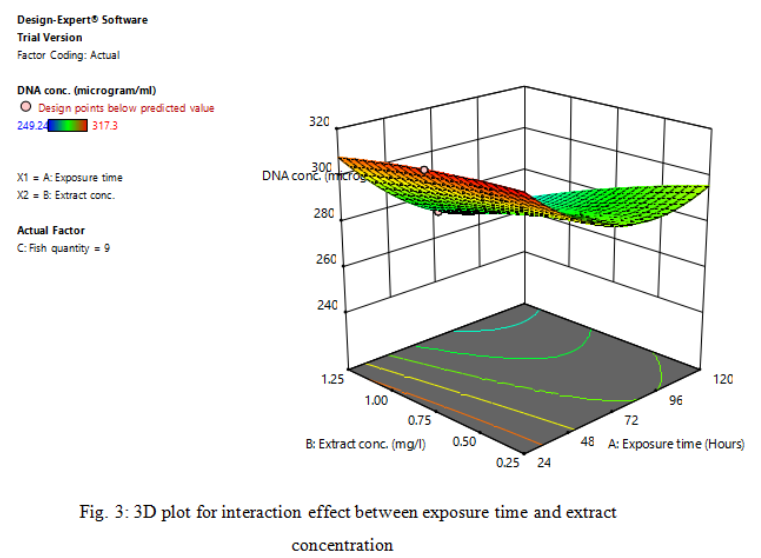

Figure 2 and 3 are contour and three dimensional plots respectively for interaction between exposure time and extract concentration. From the plot, there is a mix of positive and negative quadratic effect on extract concentration. The combination that have the highest effect on DNA concentration is exposure time of $24 \mathrm{hrs}$ and extract concentration of $1.25 \mathrm{mg} / \mathrm{l}$.

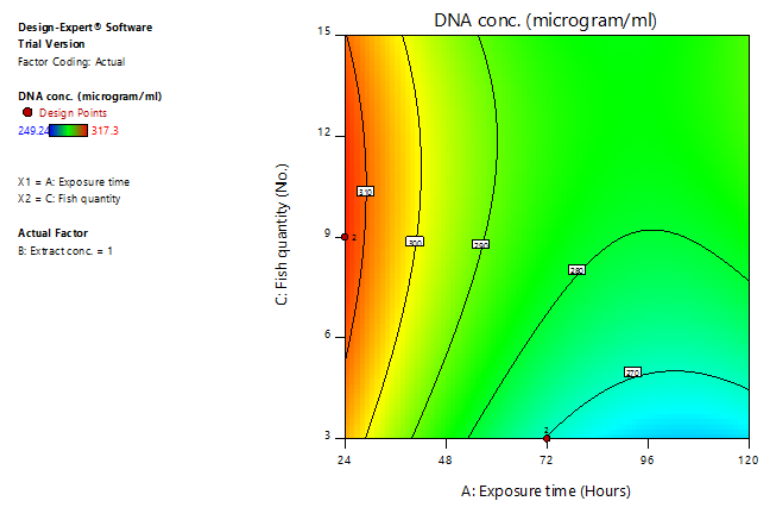

Fig. 4: Contour plot for interaction effect between exposure time and fish quantity

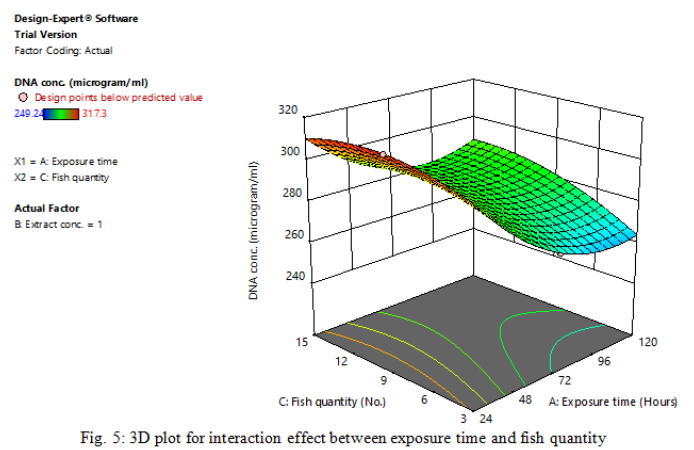

Figure 4 and 5 are contour and three dimensional plots respectively for interaction between exposure time and fish quantity. Their is also a mix of positive and negative interactions between fish quantity and exposure time. 


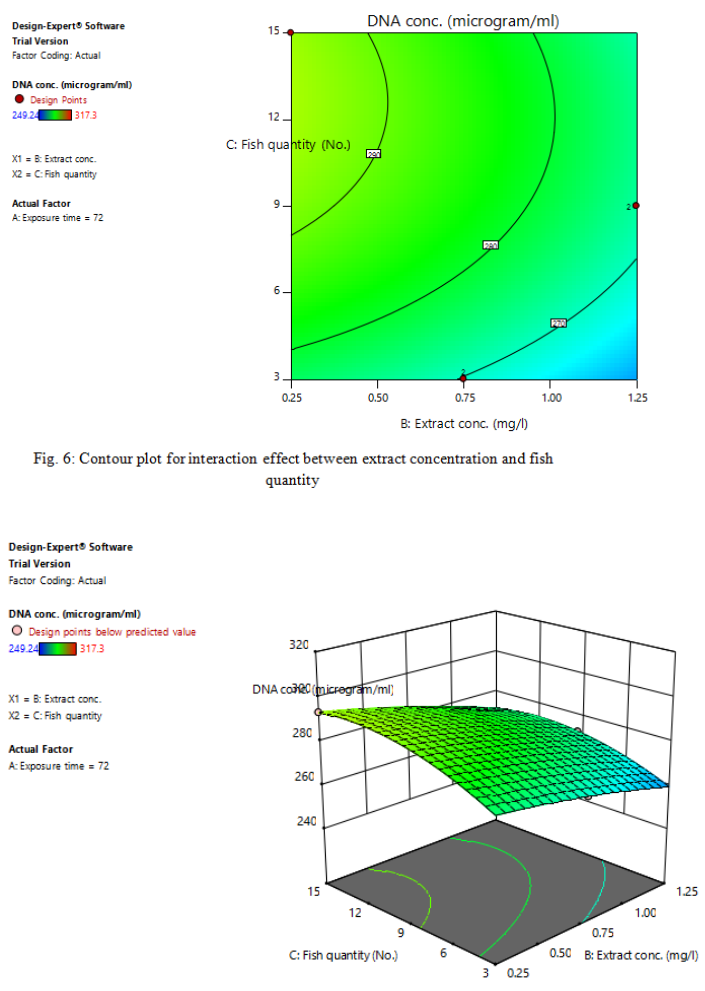

Fig. 7: 3D plot for interaction effect between extract concentration and fish quantity

Figure 6 and 7 are contour and three dimensional plots respectively for interaction between extract concentration and fish quantity. As extract concentration and fish quantity increases, DNA concentration decreases in the opposite direction. This phenomenon is as a result of negative quadratic effect of extract concentration and fish quantity.

\section{Maximal effect of process parameters on DNA concentration}

The condition that had the greatest effect on DNA concentration is the set of condition that caused the greatest reduction in DNA concentration. For the predicted values (table 2), least DNA concentration is $249.24 \mu \mathrm{gram} / \mathrm{ml}$. For the actual values (table 2), least DNA concentration is 254.73 $\mu \mathrm{gram} / \mathrm{ml}$. Process conditions that effect this changes are; exposure time 120 hours, extract concentration $0.25 \mathrm{mg} / \mathrm{l}$ and fish quantity 6 . A small percentage difference exist between the actual and predicted value (2.16\%). This percent error of actual values compared to the predicted values indicate that the regression model developed in this study was accurate in representing the overall data and reliable in predicting the response (DNA concentration) at any given conditions within the study range.

\section{Effect of extract exposure on DNA concentration}

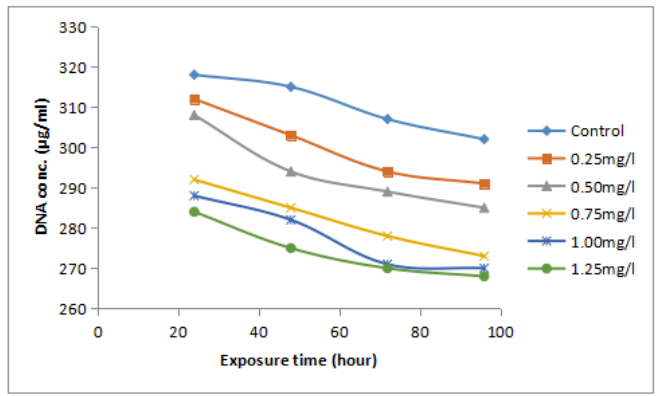

Fig 8: Effect of varied concentration of Nicotina tobaccum with time in aqua media on African catfish juvenile deoxyribonucleic acid (DNA) concentration

From figure 8, as exposure time increased, all the concentrations of Nicotiana tobacum caused decrease in the concentration of DNA. Decrease in DNA concentration were in the following ascending sequential order; $0.25 \mathrm{mg} / \mathrm{l}$, $0.50 \mathrm{mg} / 1,0.75 \mathrm{mg} / 1,1.00 \mathrm{mg} / \mathrm{l}$ and $1.25 \mathrm{mg} / \mathrm{l}$. This implies that the highest concentration $(1.25 \mathrm{mg} / \mathrm{l})$ had the highest effect. Parveen et al., ${ }^{[11]}$, reported significant reduction in DNA content in Clarias batrachus exposed to endosulfan. Tayyaba et al., ${ }^{[12]}$, attributed decrease in DNA concentration to the increased activity of DNAase. Monali and Deepronil [13], suggested that significant decrease in DNA concentration in fish tissues signifies that pollutants impaired the process of protein formation. Lebailly et al., ${ }^{[14]}$, asserted that when fish are exposed to genotoxic compounds DNA damage could directly be induce and through other mechanisms, such as oxidative stress or inflammatory processes.

\section{Conclusion}

Unguided application of pesticides and piscicides including leave extracts in aquatic habitat can cause unpleasant concerns in aquatic life. This is shown in the reduction of DNA concentration in the muscles of African catfish (Clarias gariepinus) by Nicotiana tobacum leave extract.

In this study, it was evident that factors such as pollutant concentration, fish quantity in the specified aquatic environment, and exposure time are all essential parameters or factors that effect physiological changes in African catfish (Clarias gariepinus). From the central composite design (CCD), process condition that has the maximum effect on DNA concentration in the fish muscle is; exposure time 120 hours, extract concentration $0.25 \mathrm{mg} / \mathrm{l}$ and fish quantity 6 . Exposure time, therefore is seen to have the most significant effect on DNA concentration.

Following these observations, it is hence necessary to effectively regulate and monitor the use of non registered plant materials, though useful, as an option for controlling pests in aquatic habitat.

\section{References}


[1]. Sokunvary, O., Voleak, N., Huykhim, U., Koemlin, R., Voleak, Y., Samell, K. and Sin, C. (2017). Phytochemical analysis of different extracts of leaves of Nicotiana tobacum L. of Cambodia. Asian Journal of Pharmacognosy, 1(3): 18-26.

[2]. Atanda, A.N. (2012). Fish Species Diversification in Agriculture for the Success of the Agriculture Transformation Agenda: The Role of Tilapia Production; Fisheries Society of Nigeria (FISON) Annual Public Lecture, Lagos, Nigeria.

[3]. Anetekhai, M.A. (2013). Catfish Aquaculture Industry Assessment in Nigeria. Seisay, M. and Nouala, S.A. edited. Published by Inter-African Bureau for Animal Resources, African Union.

[4]. NBS (2012). Consumption pattern in Nigeria 2009/2010. National Bureau of Statistics. Preliminary report 2012. $71 \mathrm{p}$.

[5]. Lal, K.K., Singh, R.K., Mohindra, V., Singh, B. and Ponniah, A.G. (2003). "Genetic Makeup of Exotic Catfish, Clarias gariepinus in India." Asian Fisheries Science, 16: 229-234.

[6]. Teugels, G.G. (1996). "Taxonomy, Phylogeny and Biogeography of Catfishes (Ostariophysi, Siluroidei): An Overview." Aquatic Living Resources, 9: 9-34.

[7]. Knapp, E. (2004) Nomenclatural changes and a new sectional classification in Nicotiana (Solanaceae) Taxon. 53(1):73-82.

[8]. Jegede, T. and Olanrewaju, B. (2012). Piscicidal effect of tobacco (Nicotiana tobaccum) leaf dust on african giant catfish (Heterobranchus bidorsalis) fingerlings.
Agriculture and Biology Journal of North America, 3(11): 435-438.

[9]. Odugbemi, T. (2008). A text book of medicinal plants from Nigeria. University of Lagos press, Lagos, Nigeria.

[10]. Ali M.O., Mamat R., Najafi G., Yusaf T. and Ardebili S.M.S. (2015). Optimization of Biodiesel-Diesel Blended Fuel Properties and Engine Performance with Ether Additive Using Statistical Analysis and Response Surface Methods. Energies, 8, 14136-14150.

[11]. Parveen, A., and Vasanta, N. (1986). Effects of Endosulfan on the Nucleic Acid Content in Different Tissues of Freshwater Fish, Clarias batrachus. Proceedings of the 7th National Symposium on Industrial and Social Life Science, 31-38 p.

[12]. Tayyaba, K., Hasan, M., Islam, F. and Khan, N.H. (1981). Organophosphate Pesticide Metasystox Induced Regional Alternation in Brain Nucleic Acid Metabolism. Indian Journal of Experimental Biology, 19: 688-690.

[13]. Monali, C. and Deepronil, R. (2017). Genomic \& Biochemical Changes in Fishes Due to Pesticide Pollution. Journal of Environmental Science, Toxicology and Food Technology, 11(5): 2319-2402.

[14]. Lebailly P, Vigreux C, Lechevrel C, Ledemeney D, Godard T, Sichel F, LeTalaer Y, Henry-Amar M, Gauduchon P. 1998a.

[15]. DNA damage in mononuclear leukocytes of farmers measured using the alkaline comet assay: Discussion of critical parameters and evaluation of seasonal variations in relation to pesticide exposure. Cancer Epidemiol Biomarkers Prev 7:917-927. 